\title{
Perancangan E-Tracer Study berbasis Sistem Cerdas
}

\author{
Rizaldi Akbar ${ }^{[1] *}$, Mukhtar ${ }^{[2]}$ \\ Program Studi Manajemen Informatika, AMIK Indonesia ${ }^{[1],[2]}$ \\ Jalan Teuku Nyak Arief No.400 Jeulingke, Kota Banda Aceh, Aceh, Indonesia \\ rizaldiakbar@amikindonesia.ac.id ${ }^{[1]}$, mukhtar@amikindonesia.ac.id ${ }^{[2]}$
}

\begin{abstract}
The use of tracer studies is a mediation in measuring the performance of graduates, but the most interesting thing here is where the application of tracer studies is not provided free of charge, most universities have complex problems such as lack of funds, facilities to human resources in the IT field which makes tracer study not widely used or spread on various Higher Education websites. Related to this, it is hoped that intelligent system-based e-tracer study can help universities get a decision and an e-tracer study is developed in the form of open-source so that it can be used and developed free of charge by every university in Indonesia. From the results of the study, it can be concluded that this research successfully designed an etracer study that was built with a Codeigniter framework and supporting programming languages consisting of HTML, CSS, Jquery, JavaScript, JSON, AJAX, Boostrap as media in the design of the interface. While PHP as a server-side and MySQL as a database. The design process is carried out through the stages of the formulation of the problem, the study literature, the collection of data needs analysis, system design and application testing. In the testing process using the black box method and measured using the usability test method on the measurement of 5 (five) components consisting of; learnability, efficiency, memorability, errors, and satisfaction obtained through the distribution of questionnaires to students and alumni. the etracer study uses questionnaires based on regulations and career center guidelines and 2017 tracer study, and in the alumni filling process does not use the register module but alumni simply fill in the registration form provided, this is done based on the usability test results that the AMIK Indonesia alumni really dislike the process register and activation.
\end{abstract}

Keywords—design; tracer study; expert system.

Abstrak - Penggunaan tracer study merupakan mediasi dalam pegukuran kinerja lulusan, tetapi hal yang paling menarik disini adalah dimana aplikasi tracer study tidak disediakan secara gratis, kebanyakan perguruan tinggi memiliki masalah yang komplek seperti kurangnya dana, fasilitas hingga SDM dalam bidang IT yang membuat tracer study tidak banyak digunakan maupun tersebar di berbagai website Perguruan Tinggi. Terkait hal tersebut, diharapkan e-tracer study berbasis sistem cerdas dapat membantu perguruan tinggi mendapatkan suatu keputusan dan e-tracer study dikembangkan dalam bentuk open source sehingga dapat digunakan dan dikembangkan secara gratis oleh setiap Perguruan Tinggi di Indonesia. Dari hasil penelitian maka dapat disumpulkan bahwa penelitian ini berhasil merancang e-tracer study yang dibangun dengan framework codeigniter dan bahasa pemograman pendukung terdiri dari HTML, CSS, Jquery, Java Script, JSON, AJAX, Boostrap sebagai media dalam perancangan antar muka.
Sedangkan PHP sebagai server side dan MySQL sebagai database. Pada proses perancangan dilakukan melalui tahapan rumusan masalah, literatur studi, pengumpulan datam analisis kebutuhan, desai system dan pengujian aplikasi. Pada proses pengujian menggunakan metode blackbox dan diukur dengan menggunakan metode usabilitity test pada pengukuran 5 (lima) komponen terdiri dari; learnability, efficiency, memorability, errors, dan satisfaction yang didapatkan melalui penyebaran kuisioner kepada mahasiswa dan alumni. e-tracer study menggunakan kuisioner berdasarkan peraturan dan pedoman pusat karir dan tracer study 2017 , dan pada proses pengisian alumni tidak menggunakan modul register tetapi alumni cukup mengisi form pendaftaran yang disediakan, hal ini dilakukan berdasarkan hasil usability test bahwa alumni AMIK Indonesia sangat tidak menyukai proses register dan aktivasi.

Kata Kunci-perancangan; tracer study; sistem cerdas.

\section{PENDAHULUAN}

Tracer study merupakan salah satu program yang dilakukan oleh seluruh perguruan tinggi di Indonesia, sebagai bentuk pengawasan alumni yang telah dihasilkan oleh perguruan tinggi, dalam artian setiap perguruan tinggi selalu mengevaluasi pelaksanaannya. Dalam proses penggunaan etracer study, pengumpulan data kuesioner seperti tentang lulusan yang telah bekerja, untuk mengetahui berapa lama seorang alumni bisa mendapatkan pekerjaan setelah lulus, dan beberapa hasil kuesioner sebagai informasi untuk digunakan sebagai referensi kurikulum dan peningkatan pembelajaran [1]. Universitas perlu melakukan pencarian data untuk lulusanya, data ini bisa digunakan dalam berbagai kebutuhan, dengan adanya e-tracer study menjadi media alternatif yang lebih efektif untuk mengumpulkan data lulusan [2].. Layanan e-tracer study dikatakan baik dapat memberikan informasi bagi perguruan tinggi dan bahan dalam perbaikan kurikulum serta penelusuran alumni secara detail untuk mengetahui kepuasan stakeholders terhadap lulusan perguruan tinggi tersebut [3].

Saat ini, menurut Badan Pusat Statistik (BPS) jumlah pengangguran di Indonesia Februari 2018 sebanyak 6,82 juta orang dan 12.18 di antaranya adalah pengangguran terdidik lulusan Diploma dan Universitas [4]. beberapa hal menjadi penyebab tingginya angka pengangguran berpendidikan tinggi, diantaranya ketidaksesuaian antara pemerolehan kompetensi pendidikan dengan kebutuhan atau persyaratan lapangan kerja yang tersedia, atau ketidakseimbangan antara permintaan dengan penawaran, serta kualitas SDM yang dihasilkan [5]. Selain itu, Kemenristek Dikti telah mengeluarkan Form Kuisioner Standar Tracer study 2017 
yang dapat digunakan sebagai acuan dalam pembuatan kuisioner. Tetapi hal yang paling menarik disini adalah, dimana aplikasi berbasis web untuk Tracer study tidak disediakan secara gratis [6], kebanyakan perguruan tinggi memiliki masalah yang komplek seperti kurangnya dana, fasilitas hingga SDM dalam bidang IT yang membuat Tracer study tidak banyak digunakan maupun tersebar di berbagai Website Perguruan Tinggi [7]. Terkait hal tersebut, diharapkan e-tracer study berbasis sistem cerdas dapat membantu perguruan tinggi mendapatkan suatu keputusan dan e-tracer study dikembangkan dalam bentuk open source sehingga dapat digunakan dan dikembangkan secara gratis oleh setiap Perguruan Tinggi di Indonesia.

\section{LANDASAN TEORI}

\section{A. Tracer study}

Alumni merupakan sebuah aset bagi sebuah lembaga pendidikan, keberhasilan sebuah lembaga pendidikan dalam melakukan proses belajar mengajar terhadap lulusannya. Dalam pengelolaan lulusan dapat dilakukan setelah mahasiswa menyelesaikan studinya atau sebelum menyelesaikan studi. Sebagian perguruan tinggi mempersiapkan alumni saat awal mendaftar dan diberikan kesiapan kepada mahasiswa untuk menghadapi masa setelah lulus nantinya, seperti membuat pelatihan, bagaimana proses pencarian dan tes kerja dan sebagainya sebagai kesiapan setelah lulus [8].

E-Tracer juga melacak dan mengukur kinerja lulusan sehingga dapat diperoleh indikator yang jelas tentang jumlah, profil dan sebagainya [9]. Bagi alumni sistem e-tracer adalah cara tepat dalam mengatasi permasalahan yang ada, karena sistem alumni e-tracer dapat diakses oleh calon alumni dan pemangku kepentingan yang ingin melihat informasi database alumni dimanapun dan kapan saja yang terhubung dengan Internet [10].

\section{B. Sistem Cerdas}

Sistem Cerdas adalah ilmu pengetahuan yang bergerak dalam pembuatan mesin yang cerdas. Mesin yang cerdas dapat diartikan sebagai mesin yang dapat melakukan hal-hal tertentu yang memerlukan kecerdasan apabila dilakukan oleh manusia [11]. Sistem pakar atau sebutan sistem cerdas dengan menerapkan beberapa metode, maka akan menghasilkan sistem yang dapat memberikan rekomendasi solusi terbaik [12].

Sistem cerdas telah banyak diterapkan diberbagai lembaga maupun institusi, dengan penyajian serta mengembangkan knowledge-based dan penerapan rule yang ditawarkan oleh para ahli dapat memberikan solusi dalam pengambilan keputusan dengan cepat [13]. Sistem pakar juga dapat memprediksi suatu nilai dari rangkaian waktu yang dianalisis, menggunakan nilai prediksi dan aturan inferensi untuk memverifikasi setiap data dan algoritma dari sistem pakar, sistem pakar juga memiliki banyak metode dan algoritma yang disesuaikan dengan berbagai kasus [14]. Berbagai algoritma sistem pakar yang banyak digunakan sebagai pengembangan sistem seperti; K-Means, Neuro-Fuzzy Sistem, Black Hole Algorithm, Neural Networks [15].

\section{Open Source}

Menurut [16] Perangkat lunak open source adalah evolusi dari gerakan Perangkat Lunak Bebas tahun 1980an. Didirikan oleh Richard Stallman, seorang insinyur di MIT's AI Laboratory, Perangkat Lunak Bebas dimaksudkan untuk menciptakan, dari bawah ke atas, sebuah Unix gratis yang disebut GNU ("GNU" bukan Unix "). Meskipun tidak mencapai tujuan awal, Stallman's Free Software Foundation (FSF) menghasilkan banyak lisensi seperti GNU General Public License untuk perangkat lunak bebas (GPL), serta sejumlah utilitas yang berguna dalam penciptaan sistem operasi bebas yang disebut Linux. Memahami Anotasi Pengembangan Perangkat Lunak Open source analisis pertama yang ketat dari metodologi perangkat lunak Open source adalah sebuah teknologi ekonomi dan dinamika psikososial [17]. Sumber terbuka (Open source) merupakan sistem pengembangan yang tidak dikoordinasi oleh seseorang maupun kelompok, tetapi oleh berbagai pengembang aplikasi dapat memanfaatkan kode sumber (source-code) yang tersebar dan tersedia bebas [18].

\section{METODE}

\section{A. Rancangan Penelitian}

Rancangan penelitian yang digunakan adalah penelitian terapan, dimana bertujuan untuk menguji teori atau suatu ilmu yang sudah ada untuk keperluan praktis dan dapat bermanfaat secara langsung dalam praktik di dunia nyata. Tujuan dari penelitian terapan (applied research) yaitu jenis penelitian yang diarahkan untuk mendapatkan informasi yang dapat digunakan untuk memecahkan suatu masalah.

Metode pengumpulan data dilakukan dari studi literatur, wawancara dan observasi langsung ke AMIK Indonesia. Sedangkan desain penelitian menggunakan metode eksperimental karena menghasilkan sebuah produk yaitu sistem cerdas. E-tracer study menggunakan metode FMADM untuk melakukan perhitungan terhadap hasil data yang diperoleh pada aplikasi. Aplikasi e-tracer study menggunakan framework codelnigter dan bosstrap untuk rancangan antar muka serta database MySQLi. Pada analisa sistem berjalan dan perancangan sistem digambarkan dengan Microsoft Visio 2016. Metode pengujian dilakukan dengan menggunakan metode blackbox

\section{B. Lokasi Penelitian}

Penelitian ini secara pokok akan dilaksanakan pada AMIK Indonesia. Selain itu, penelitian ini juga akan melibatkan alumni dan dosen untuk melakukan pengisian data dan mencoba aplikasi yang dibuat.

\section{Desain Penelitian}

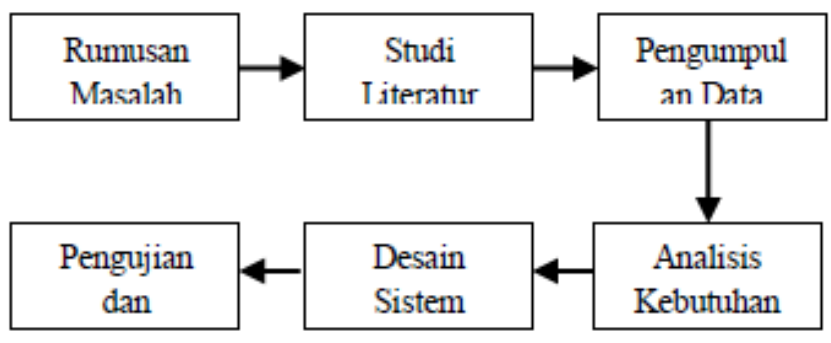

Gambar 1. Desain Penelitian 
Keterangan:

1. Rumusan Masalah

Kesulitan dalam pengembila keputusan terhadap lulusan selama ini terjadi karena data lulusan dicatat serta dilakukan secara manual. Untuk mengatasi masalah ini maka dirancanglah suatu e-tracer study sebagai sistem pendukung keputusan dengan menggunakan metode Simple Additive Weighting (SAW) untuk menentukan kriteria penilaian dan pembobotan dalam mengambil keputusan sehingga hasil dari e-tracer study tersebut dapat meningkatkan mutu Perguruan Tinggi serta pengurusan Akreditasi Program Studi nantinya.

2. Studi Literatur

Pada tahap studi literatur dilakukan dengan mempelajari literasi mengenai system pendukung metode Simple Additive Weighting (SAW) dan diterapkan pada aplikasi tracer study.

3. Pengumpulan Data

Pada tahap pengumpulan data diambil dari hasil wawancara dan hasil dari kusioner serta di analisis terkait kinerja dan kepuasan aplikasi e-tracer study dimana sampel adalah alumni dan mahasiswa.

4. Analisis Kebutuhan Sistem

Pada tahap ini dilakukan identifikasi kebutuhan input yang terdiri dari data alumni, kusioner tracer study, dan menentukan bobot dari setiap alternatif dan kriteria yang digunakan untuk proses pengambilan keputusan dari penerapan metode Simple Additive Weighting (SAW), sedangkan pada identifikasi kebutuhan output keluaran yang dihasilkan dari aplikasi ini adalah sebuah data alumni, pengisian kuisioner tracer study dan alternatif dan rekomendasi dari hasil pengisian kuisioner tersebut.

5. Desain Sistem

Setelah dilakukan gambaran proses pengembangan perangkat lunak maka dituangkan kedalam sebuah model desain antar muka dan data.

6. Pengujian/Evaluasi

Tahap selanjutnya dilakukan proses pengujian metode blackbox dan kemampuan system menggunakan usabilitity test dengan pengukuran 5 (lima) komponen terdiri dari; learnability, efficiency, memorability, errors, dan satisfaction yang didapatkan melalui penyebaran kuisioner kepada mahasiswa dan alumni.

\section{HASIL DAN IMPLEMENTASI}

\section{A. Hasil Rancangan Sistem}

Dengan penyesuaian rancangan maka didapatkan rancangan dasar pengembangan aplikasi Tracer study yang terdiri dari rancangan masukan :

\section{NIM}

PT / Prodi

- Nama Lengkap

- Angkatan

- Jenis Kelamin

- Status
- Email

- Alamat

- Daftar Pertanyaan Kuisioner

- User atau Admin

Sedangkan Analisa keluaran terdiri dari:

- $\quad$ Rekap Pengisi Kuisioner

- Validasi Kuisioner

- Data Kuisioner

- Grafik, dan

- Laporan

\section{B. Rancangan Layar}

Adapun hasil dari rancangan aplikasi tracer study sebagai berikut:

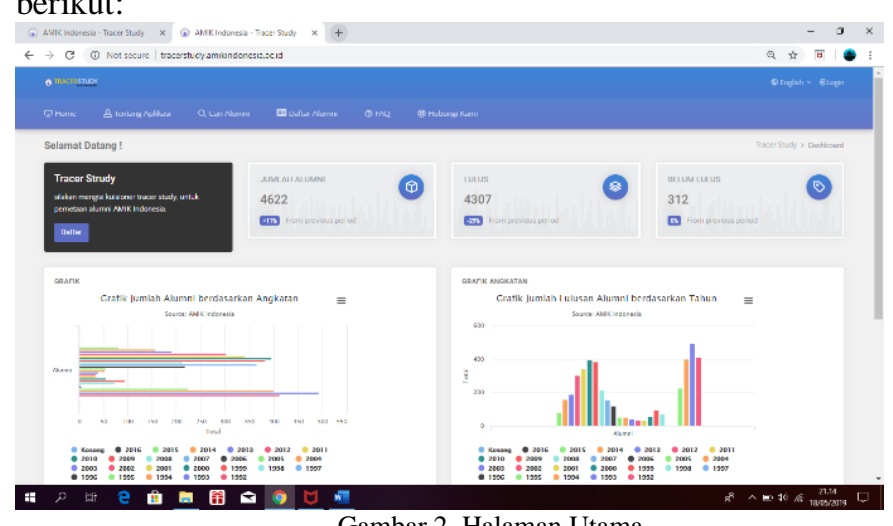

Gambar 2. Halaman Utama

Halaman Utama pertama ketika di akses, halaman ini terdiri dari informasi seperti; tentang aplikasi, cari alumni, daftar alumni, FAQ, dan hubungi kami. Untuk melakukan pendaftaran alumni dapat mengakses pada halaman daftar alumni, seperti terlihat pada gambar 3 .

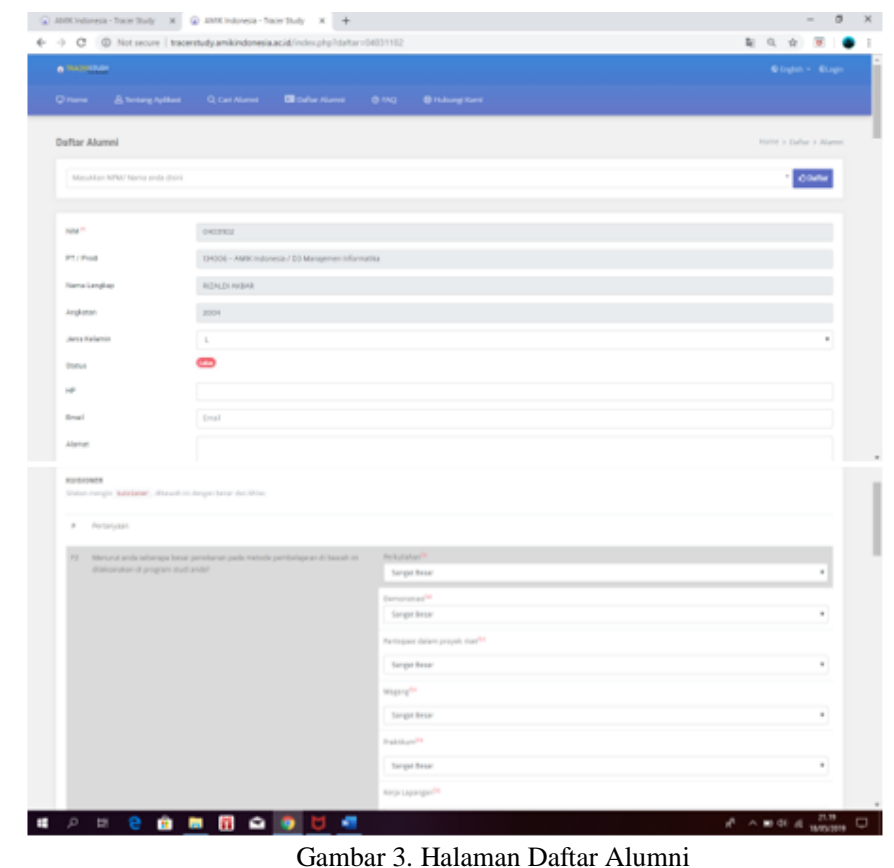


Pada halaman ini, alumni memasukan NIM atau nama sehingga nantinya halaman pendaftaran akan ditampilkan secara utuh. Halaman ini, terdiri dari; NIM, PT/Prodi, Nama Lengkap, Angkatan, Jenis Kelamin, Status, HP, Email, Alamat, dan pertanyaan kuesioner yang telah disesuaikan menurut peraturan panduan tracer study 2017 yang dikeluarkan oleh Kemeristek Dikti. Untuk mengakses halaman admin, pengelola tracer study melakukan login dan mengisi username dan password seperti pada gambar 4.

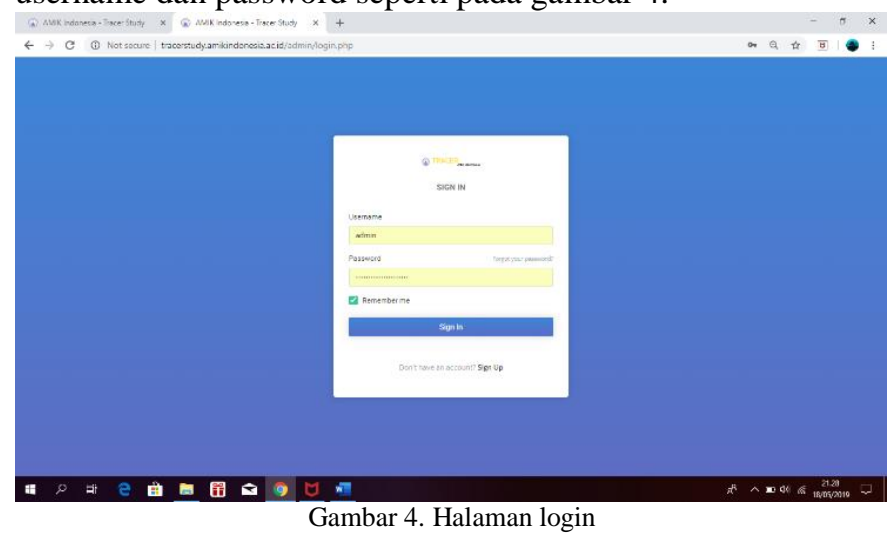

Setelah melakukan proses login, pengelola tracer study akan di arahkan ke halaman admin seperti terlihat gambar 5.

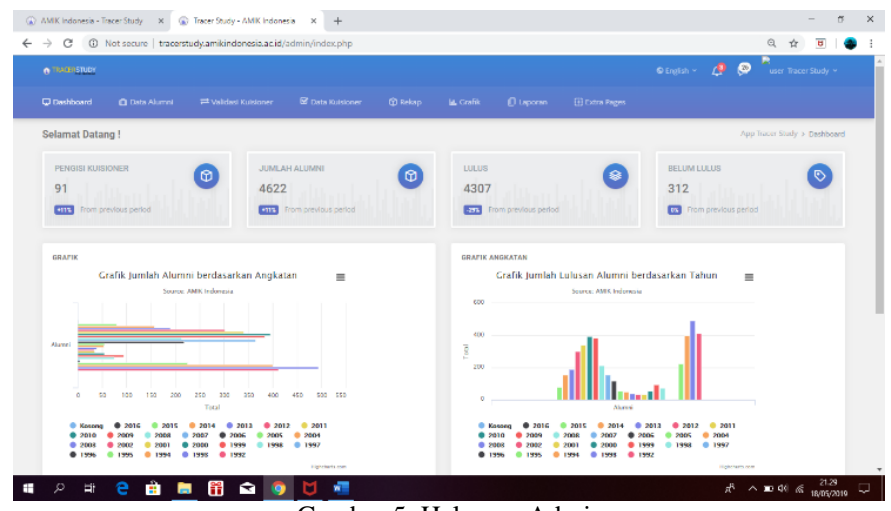

Gambar 5. Halaman Admin

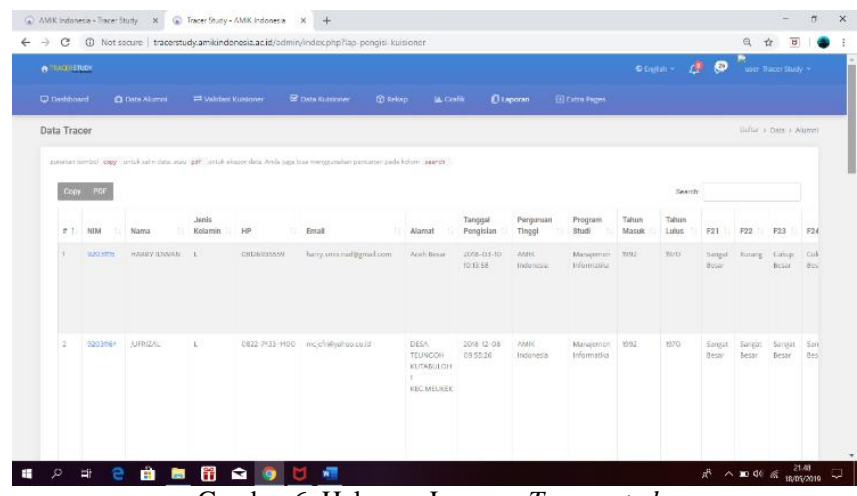

Gambar 6. Halaman Laporan Tracer study

Pada halaman ini terdiri dari informasi menu; dashboard, data alumni, validasi kuisioner, Data kuisioner, rekap, grafik, laporan tracer study, Pada menu rekap terdapat submenu kategori, pengisi kuisioner, validasi kuisioner, dan data kuisioner sedangkan pada menu grafik terdiri dari submenu angkatan dan semua angkatan. Pada menu laporan terdapaat submenu per angkatan dan pengisian kuisioner seperti terihat pada gambar 6 .

\section{PENUTUP}

Dari hasil penelitian maka penelitian ini berhasil merancang e-tracer study yang dibangun dengan framework codeigniter dan bahasa pemograman pendukung terdiri dari HTML, CSS, Jquery, Java Script, JSON, AJAX, Boostrap sebagai media dalam perancangan antar muka. Sedangkan PHP sebagai server side dan MySQL sebagai database. Pada proses perancangan dilakukan melalui tahapan rumusan masalah, literatur studi, pengumpulan datam analisis kebutuhan, desai system dan pengujian aplikasi. Pada proses pengujian menggunakan metode blackbox dan diukur dengan menggunakan metode usabilitity test pada pengukuran 5 (lima) komponen terdiri dari; learnability, efficiency, memorability, errors, dan satisfaction yang didapatkan melalui penyebaran kuisioner kepada mahasiswa dan alumni. e-tracer study menggunakan kuisioner berdasarkan peraturan dan pedoman pusat karir dan tracer study 2017, dan pada proses pengisian alumni tidak menggunakan modul register tetapi alumni cukup mengisi form pendaftaran yang disediakan, hal ini dilakukan berdasarkan hasil usability test bahwa alumni AMIK Indonesia sangat tidak menyukai proses register dan aktivasi.

Pada penelitian selanjutnya e-tracer study ini dapat dipadukan dengan metode system pakar lainnya seperti Naïve Bayes, K-Means, Dempster Shafer, Case Based Reasoning (CBR), dan sebagainya yang bisa digunakan sebagai alat untuk mengukur kinerja, pengelompokkan dan prediksi lulusan.

\section{UCAPAN TERIMA KASIH}

Ucapan terima kasih peneliti kepada Direktorat Riset dan Pengabdian Masyarakat Direktorat Jenderal Penguatan Riset dan Pengembangan Kementerian Riset, Teknologi, dan Pendidikan Tinggi Tahun 2019 sebagai penyandang dana penelitian dalam bentuk dana hibah skim Penelitian Dosen Pemula (PDP), ucapan terima kasih juga kepada LPPM AMIK Indonesia yang telah membimbing sehingga hasil penelitian sesuai dengan harapan, dan tidak lupa pula kepada Civitas Akademi AMIK Indonesia serta stackholder yang telah membimbing selesainya hasil penelitian ini.

\section{REFERENCES}

[1] Noviyantono, E., 2012, June. Integration System Of Web Based And SMS Gateway For Information System Of Tracer study. In International Conference on Engineering and Technology Development (ICETD).

[2] Marisa, F., Efendi, D.U. and Mumpuni, I.D., 2016, October. Tracer study System Portal-Based Social Network To Optimize Data Collection On Higher 
Education Graduates. In Prosiding International conference on Information Technology and Business (ICITB) (pp. 19-24).

[3] Chandra, R., Renny, R. and Ruhama, S., 2014. Pengembangan Sistem E-tracer study pada Perguruan Tinggi. Konferensi Nasional Sistem Informasi 2014, pp.394-398.

[4] Badan Pusat Statistik (BPS). 2018. Februari 2018: Tingkat Pengangguran Terbuka (TPT) sebesar 5,13 persen, Rata-rata upah buruh per bulan sebesar 2,65 juta rupiah.

URL: https://www.bps.go.id/pressrelease/2018/05/07/1484/febr uari-2018--tingkat-pengangguran-terbuka--tpt--sebesar-513-persen--rata-rata-upah-buruh-per-bulan-sebesar-2-65juta-rupiah.html. Diakses Tanggal 24 Juli 2019

[5] Panduan Pusat Karir. 2019. Tentang Tracer Study. URL: http://pkts.belmawa.ristekdikti.go.id/index.php/site/about. Diakses Tanggal 24 Juli 2019.

[6] Akbar, R., 2019. E-Tracer Study Based on Expert Systems (A Case Study at AMIK Indonesia). EPHInternational Journal of Science And Engineering (ISSN: 2454-2016), 5(5), pp.12-17.

[7] Akbar, R. and Mukhtar, M., 2019. Evaluasi e-Tracer Study menggunakan HOT (Human-OrganizationTechnology) Fit Model. Jurnal JTIK (Jurnal Teknologi Informasi dan Komunikasi), 3(2), pp.46-51.

[8] Ananda, D., 2016. Pemodelan Sistem Informasi Layanan Karir Dan Alumni Politeknik XYZ. Semnasteknomedia Online, 4(1), pp.4-11.

[9] Ependi, U., 2015, July. Pengembangan E-Trace Alumni Dengan Menggunakan Pendekatan Metode Agile. In Seminar Nasional Informatika (SEMNASIF). (Vol. 1, No. 4).
[10] Devi, U., Prihambodo, H.S. and Ahmad, H.M., 2015. ETracer System Design of Master of Information Technology Bina Darma University Alumni Using Agile Methods Model.

[11] Mubarak, R., 2018, June. Sistem Cerdas Berbasis Konsep Fuzzy Logic Untuk Evaluasi Kinerja Karyawan. In ESIT (Vol. 11, No. 2, pp. 36-40).

[12] Aribowo, A.S., 2015. Pengembangan Sistem Cerdas Menggunakan Penalaran Berbasis Kasus (Case Based Reasoning) Untuk Diagnosa Penyakit Akibat Virus Eksantema. Telematika, 7(1).

[13] Gumbricht, T., Roman-Cuesta, R.M., Verchot, L., Herold, M., Wittmann, F., Householder, E., Herold, N. and Murdiyarso, D., 2017. An expert system model for mapping tropical wetlands and peatlands reveals South America as the largest contributor. Global change biology, 23(9), pp.3581-3599.

[14] Mazurkiewicz, D., 2015. Maintenance of belt conveyors using an expert system based on fuzzy logic. Archives of Civil and Mechanical Engineering, 15(2), pp.412-418.

[15] Azar, A.T. and Vaidyanathan, S. eds., 2015. Computational intelligence applications in modeling and control. Springer International Publishing.

[16] Asiri, S., 2003. Open source Software. SIGCAS Computers and Society, 33(1), p.2.

[17] Feller, J. and Fitzgerald, B., 2002. Understanding Open source software development (pp. 143-159). London: Addison-Wesley.

[18] Website Resmi Kominfo. 2017. Open Source di Kominfol: Program Prioritas. URL: https://kominfo.go.id/index.php/content/detail/3434/Open +Source+di+Kominfo/0/program_prioritas. Diakses $\begin{array}{llll}\text { Tanggal } & 24 & \text { Oktober }\end{array}$ 